\title{
Some help for the dudes and praise to the experts
}

\section{John Andrews}

BIRDWATCHING beginners are badly served by publishers, their needs being met neither by the abundant field guides, which are mostly too wide-ranging and complex for the newcomer, nor by the glossy coeditions "packaged" to sell in several countries rather than to inform in one. One bright side to the recession has been that the latter have vanished from the scene, though it may be mere coincidence that two books have appeared which every beginner should own.

John Gooders' The Bird Seeker's Guide (André Deutsch; hbk £6.95, pbk £3.50) gives invaluable instruction on where to find birds in Britain. The opening chapters contain general guidance on the ways in which bird populations change with the seasons and on the characteristic group of species or

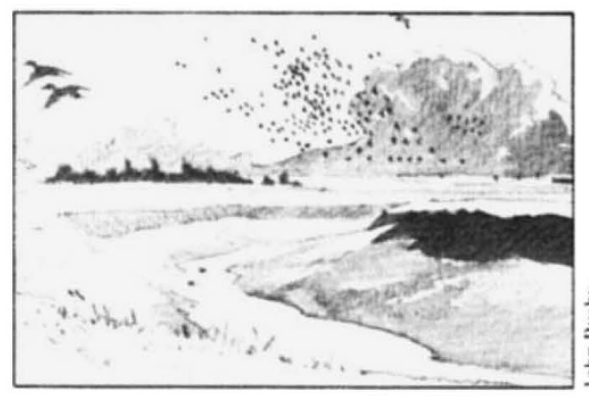

"bird community" to be found in each major habitat type. The main text comprises species accounts, each containing brief identification notes which concentrate on key points for separating similar species, and a description of the preferred habitats and distributions. Where necessary for uncommon species, likely locations are given but commendable care has been taken to avoid reference to precise sites in the case of vulnerably rare birds.

Anyone venturing into the field and encountering other birders will rapidly come up against the substantial jargon of ornithology, which ranges from arcane scientific terms to offensive slang. For instance, there are about 40 different areas of a bird's plumage each with its own name and one must know them all to make clear written descriptions of birds seen in the field: if you don't, you are clearly a "casual birdwatcher without serious commitment" or, more succinctly, a dude. No longer need you flounder in ornithology's information gap. The Birdwatcher's Dictionary by Peter Weaver ( $\mathrm{T}$. \& A.D. Poyser, £5) defines over 1,100 terms and abbreviations, to enable the newly-fledged birder to match insult or erudition with equal ease. Crisply illustrated by Mike Hodgson, the text is thoroughly instructive and makes good browsing as well as useful reference.

By contrast with the needs of the beginner, scientific ornithology in Britain is usually well served by carefully researched and presented books. This year has seen only a single addition to the list but one eagerly awaited by the great number of amateur ornithologists who contributed to the Birds of Estuaries Enquiry, which ran from 1969 to 1975 . Every winter for those six years the total wader populations of all the estuaries of Britain and Ireland were counted in perhaps the most ambitious and demanding ornithological survey ever undertaken. Substantial organization was needed to find and coordinate the teams working each area. Few of the thousand people who took part began as skilled wader counters, so techniques had to be evolved, imparted and checked for accuracy. Some personal commitment was also required: it is no light task to rise in the January small-hours, drive to a distant estuary for a dawn high tide and strive to count whirling flocks of birds, sometimes many thousands strong, with rainspattered lenses or frost-numbed fingers. Now the intangible and sometimes illusive rewards of the experience take a more practical form in A.J. Prater's Estuary Birds of Britain and Ireland (T. \& A.D. Poyser, £14), which draws together the results of this mammoth study and much more information besides.

The opening chapters examine the nature of estuaries and the ways in which birds utilize them, including consideration of the factors which influence feeding success. Turning to migration and distribution in Western Europe, the author, who was the national survey organizer, discusses in particular the complexity of wader movements between estuaries which ringing work is now unravelling. Two chapters are devoted to threats to estuaries - barrages and reservoirs, airports, agriculture, energy generation, pollution and leisure all figure. This is a slightly disappointing section of an otherwise excellent work, with too much emphasis on the nature and scale of impact and too little on the causes and justification - or lack of it - for the threats themselves: some startlingly costly and grandiose ways of wasting public money continue to be dreamed up for our estuaries. Returning to his main theme, Tony Prater describes the organization of the Enquiry, discusses count methodology and considers the vexed question of assessment criteria.

About half of the text comprises detailed summaries of present knowledge, both estuary by estuary and species by species. Copious maps and tables make much of the textual information available at a glance: there is an excellent bibliography, some photographs of marginal usefulness and many charming drawings by John Busby. Overall, a valuable book of a remarkable survey. Other nations please copy.

In turn, Britain, overrun by mink and, to some opinions, by Canada geese, might do

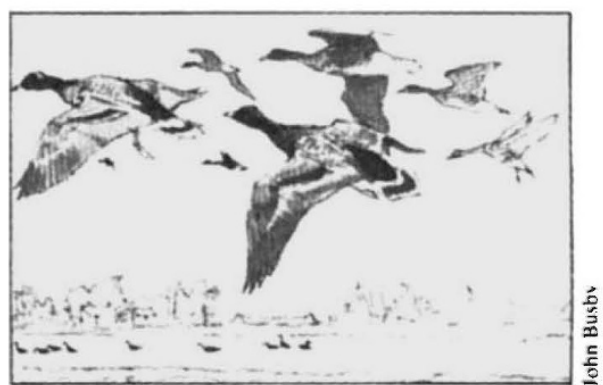

well to copy Western Australia in evolving a firm policy to control importation and translocation of potentially harmful wildlife. As a step in this direction, the States Agriculture Protection Board initiated a study which became, in the hands of John Long, the author of Introduced Birds of the World (David \& Charles, £15), a comprehensive review of every known avian introduction worldwide. $\mathrm{He}$ found records involving 425 species and for each describes its natural and introduced range, the history and outcome of its introduction, and discusses its potential for damage. And damage there has been - extinctions of native species through competition and hybridization, substantial losses of agricultural and fruit crops and, possibly, the transfer of diseases and parasites. Western Australia is to be congratulated on the book: would our own agriculture departments were as wise.

John Andrews is Head of Conservation Planning at the Royal Society for the Protection of Birds, Sandy, Bedfordshire.

\section{The dissent of woman}

\section{Andrew Hill}

On Becoming Human. By Nancy $\mathrm{M}$. Tanner. Pp.373. ISBN hbk 0-521-23554-5; ISBN pbk 0-521-28028-1. (Cambridge University Press: 1981.) Hbk £20, \$29.95; pbk £6.95, \$10.95.

CHIMPANZEES are more like human beings than they appear. Linnaeus - the type specimen of taxonomists - originally classified the beasts in the human genus as Homo troglodytes, and scientists have continued to stress the similarities. On Becoming Human follows this tradition by proposing the chimpanzee as a model for the common ancestor of apes and man.

The book possesses a number of attractive features. Some of the latest evidence of affinity comes from work on proteins, and here we have a useful summary. There is also much on chimpanzee behaviour, emphasizing the 